\title{
Surface brooding in the Caribbean gorgonian Pterogorgia anceps
}

Received: 19 November 2009/ Accepted: 3 January 2010/Published online: 23 January 2010

(C) Springer-Verlag 2010

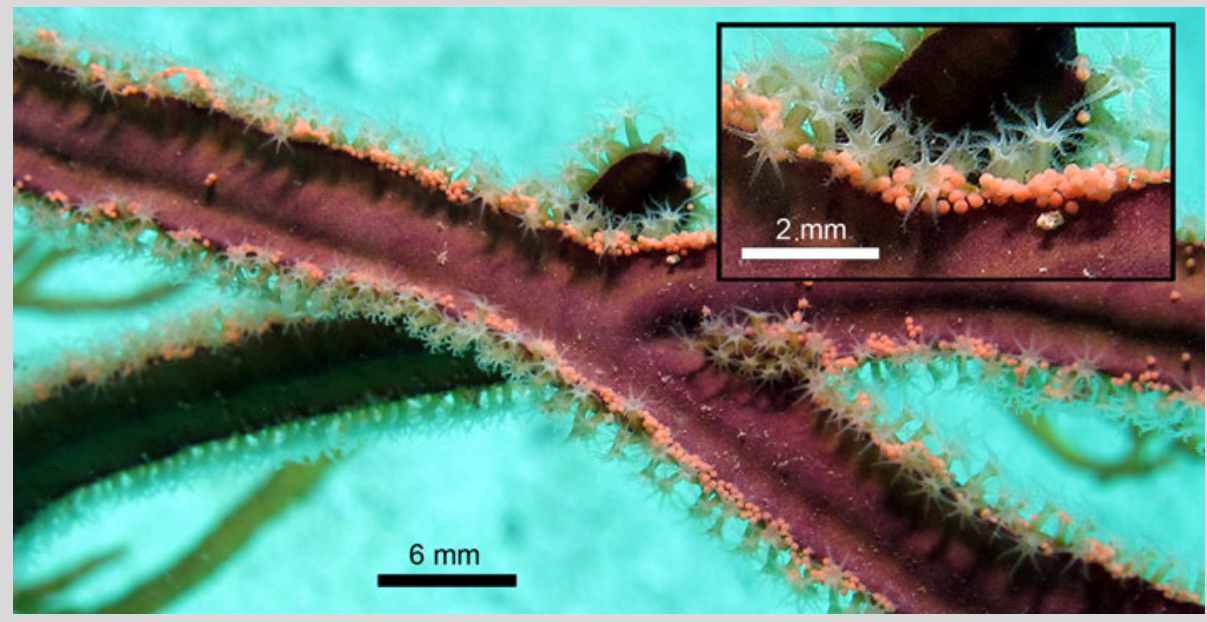

Fig. 1 Developing embryos (pink spheres, inset) that are adhered to the surface of a branch of Pterogorgia anceps

For many Caribbean gorgonian species, the timing and mode of reproduction remain unknown, making research on their fertilization, larval and recruitment ecology impossible. Some Caribbean gorgonians are synchronous spawners (Lasker et al. 1996) while some species are surface brooders, such as Pseudopterogorgia elisabethae and Briareum asbestinum. These species brood their embryos on the colony surface instead of internally (Brazeau and Lasker 1990; Gutierrez-Rodriguez and Lasker 2004). Some Indo-Pacific and Red Sea soft corals are also surface brooders including Parerythropodium fulvum fulvum and Capnella gaboensis (Benayahu and Loya 1983; Farrant 1986).

On October 22, 2009 at 9 a.m., while diving at a depth of $10 \mathrm{~m}$ on the fore reef of Carrie Bow Cay in Belize, I observed the gorgonian Pterogorgia anceps with developing embryos on its surface (Fig. 1). Of the six colonies found within a six meter radius, only two had embryos on their surface. A few embryos were collected and brought to the laboratory where they were confirmed to be fertilized but not completely developed. By 11 am on October 23, the embryos in the laboratory had completed their development and had elongated into swimming planulae. Why some gorgonians brood their larvae on their surface is unknown, but surface brooding may be an adaptation to increase fertilization success for these sessile benthic organisms (Lasker 2006).

Acknowledgments This is contribution \#812 of the Smithsonian Marine Station at Fort Pierce and \#877 of the Caribbean Coral Reefs Ecosystem program at the Smithsonian Institution.

\section{References}

Benayahu Y, Loya Y (1983) Surface brooding in the red sea soft coral Parerythropodium fulvum fulvum (Forskål, 1775). Biol Bull 165:353-369 Brazeau DA, Lasker H (1990) Sexual reproduction and external brooding by the Caribbean gorgonian Briareum asbestinum. Mar Biol 104:465-474 Farrant PA (1986) Gonad development and the planulae of the temperate Australian soft coral Capnella gaboensis. Mar Biol 92:381-392

Gutierrez-Rodriguez C, Lasker H (2004) Reproductive biology, development, and planula behavior in the Caribbean gorgonian Pseudopterogorgia elisabethae. Invert Biol 123:54-67

Lasker H (2006) High fertilization success in a surface-brooding Caribbean gorgonian. Biol Bull 210:10-17

Lasker H, Brazeau DA, Calderon J, Coma R, Kim K (1996) In situ rates of fertilization among broadcast spawning gorgonian corals. Biol Bull 190:45-55

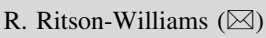

Smithsonian Marine Station at Fort Pierce, Fort Pierce, Florida 34949, USA

e-mail: williams@si.edu

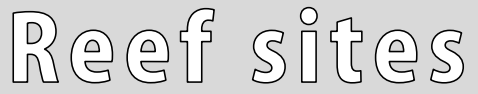

Coral Reefs (2010) 29:437

DOI $10.1007 / \mathrm{s} 00338-010-0585-6$ 